\title{
Catastrophic floods on the southern tributaries of Lake Baikal and features of the atmospheric circulation
}

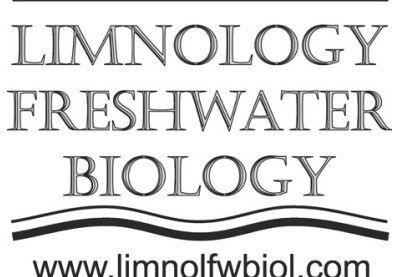

\author{
Sinyukovich V.N. ${ }^{1 *}$, Latysheva I.V. ${ }^{2}$, Makukhin V.L. ${ }^{1,2}$ \\ ${ }^{1}$ Limnological Institute, Siberian Branch of the Russian Academy of Sciences, Ulan-Batorskaya Str., 3, Irkutsk, 664033, Russia \\ ${ }^{2}$ Irkutsk State University, K. Marx Str., 1, Irkutsk, 664003, Russia
}

\begin{abstract}
We discuss the conditions for the formation of significant floods on the highly humid Hamar-Daban slope of the Baikal basin. There is historical data on the maximum water discharges of rivers, which were observed in 1971 . We characterize synoptic conditions for the flash flood-forming rainfall in July 2019. There are several changes in the modern circulation of the upper atmospheric layers causing the blocking of cyclones and an increase in the duration of rains.
\end{abstract}

Keywords: flood, runoff rate, heavy rainfall, cyclogenesis.

The most significant rain floods on the rivers flowing into the southern part of Lake Baikal are recorded for the watercourses flowing down from the northern slope of the Hamar-Daban ridge. The high humidity of this territory is primarily owing to the openness (windwardness) of the slope for the prevailing moisture transport as well as to the lowering of the Primorsky Ridge in the source of the Angara River, through which northwestern air masses enter, carrying the bulk of the moisture in the region. The annual amount of precipitation on the coast of the lake here is $500-700 \mathrm{~mm}$, and in the mountains - up to 1500 $\mathrm{mm}$ (Sinyukovich and Latysheva, 2006; Sinyukovich et al., 2019). Another important factor in the formation of high river floods in the area is small dimensions of their basins and their short length, which is associated with a somewhat remoteness of the ridge axis from Lake Baikal (30-35 km). Under these conditions, rains simultaneously cover the entire watershed area of small rivers, and a high steepness of the sloes in the river valleys of the mountainous part (up to $40-45^{\circ}$ ) determines a short slope lag and a short time of the formation of high water rises.

On larger rivers, some part of their watershed area lies in the alpine zone and zone of bald mountains, where due to slow thawing of seasonal and long-term permafrost the filtration of rain waters significantly decreases, which additionally contributes to the formation of high floods. Floods often form during snowmelt and, thus, intensify by snowmelt flood. Moreover, due to the removal of loose sediments and woody vegetation from the slopes of the mountains, temporary dams and natural reservoirs are formed on the channel networks, whose burst is accompanied by a significant increase in the water discharges and often the formation of mudflows.

Analysis of the Russian meteorological service (Rosgidromet) data on regime monitoring indicates the high average runoff modulus of the Hamar-Daban rivers (Table) reaching $20-25 \mathrm{l} /\left(\mathrm{s} \cdot \mathrm{km}^{2}\right)$, with its average value for the Baikal basin of approximately $4 \mathrm{l} /\left(\mathrm{s} \cdot \mathrm{km}^{2}\right)$ (Afanasiev, 1976).

During the highest floods, the runoff modules increase to $1000 \mathrm{l} /\left(\mathrm{s} \cdot \mathrm{km}^{2}\right)$ or more (Table), and according to the Lentransproekt data, in 1934, the runoff module on the Slyudyanka River during the burst flood exceeded $10000 \mathrm{l} /\left(\mathrm{s} \cdot \mathrm{km}^{2}\right)$.

The most significant floods in this area were observed in 1971 and 2019, which were accompanied by the destruction of infrastructure. The 1971 flood was the highest due to a record amount of precipitation: in July 1971, precipitation was $739 \mathrm{~mm}$ at the HamarDaban station (in July $2019-638 \mathrm{~mm}$ ).

High intensity and duration of precipitation that formed a flood in the south of the Baikal region in July 2019 were due to the long-term preservation of meridionality of large-scale atmospheric processes that were not only stable in time and space but also spread to significant heights, up to the lower stratosphere. At the Hamar-Daban station, on 28-29 July alone precipitation was $319 \mathrm{~mm}$, which was 1.2 times higher than monthly climate normal $(265 \mathrm{~mm})$. A shift of the cold high-altitude cyclonic eddy to the southern areas of the Irkutsk region at the end of July contributed to an increase in the pressure and thermal gradients in the zone of interaction between an anticyclone and a cyclone near the Earth's surface. Furthermore, when the polar and subtropical branches of the high-altitude

*Corresponding author.

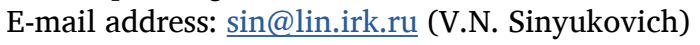


Table. Average and maximum river runoff

\begin{tabular}{|c|c|c|c|c|c|c|}
\hline \multirow{2}{*}{ River-Site } & \multirow{2}{*}{$\begin{array}{c}\text { Basin area, } \\
\mathbf{k m}^{2}\end{array}$} & \multicolumn{2}{|c|}{ Average runoff } & \multicolumn{3}{|c|}{ Maximum runoff } \\
\hline & & $\mathrm{m}^{3} / \mathrm{s}$ & $1 /\left(s \cdot \mathrm{km}^{2}\right)$ & $\mathrm{m}^{3} / \mathrm{s}$ & $1 /\left(\mathbf{s} \cdot \mathbf{k m}^{2}\right)$ & Year \\
\hline Snezhnaya - Vydrino & 3000 & 47.1 & 15.7 & 1910 & 637 & 1971 \\
\hline Khara-Murin - Murino & 1130 & 23.8 & 21.1 & 1670 & 1480 & 1971 \\
\hline Kharlakta - Baikalsk & 14.8 & 0.43 & 29.1 & 9.87 & 667 & $1980 *$ \\
\hline Utulik - Utulik & 959 & 16.8 & 17.5 & 1320 & 1380 & 1971 \\
\hline Bezymyannaya - Mangutay & 204 & 5.55 & 27.2 & 367 & 1800 & 1971 \\
\hline Pokhabikha - Slyudaynka & 63 & 1.46 & 23.2 & 38.6 & 613 & 1962 \\
\hline Slyudyanka - Slyudyanka & 56.3 & 0.82 & 14.6 & 145 & 2580 & 1971 \\
\hline
\end{tabular}

*Observations have been carrying out since 1975.

frontal zone merged into the closed high-altitude cyclonic eddy, there was an inflow of warm and humid air from the subtropical latitudes, which caused the development of cloudiness and intensive precipitation as well as the stationing of the blocking ridge in the east, determining the duration of the synoptic processes.

In general, if the past catastrophic floods were caused by the influence of the southern mainly surface cyclogenesis, at present, due to climate change and intensification of blocking processes, the role of the dynamics and activity of the high-altitude cyclogenesis and high-altitude zones is increasing.

\section{References}

Afanasiev A.N. 1976. Vodnyye resursy i vodnyy balans basseyna ozera Baikal [Water resources and water balance of Lake Baikal basin]. Novosibirsk: Nauka. (in Russian)

Sinyukovich V.N., Latysheva I.V. 2006. On characteristic features of recent climatic changes on Lake Baikal south coast. Optika Atmosfery i Okeana [Atmospheric and Oceanic Optics] 19(9): 805-809. (in Russian)

Sinyukovich V.N., Latysheva I.V., Makukhin V.L. 2019. Circulation factors for the current low water level within the Lake Baikal drainage basin. Geografiya i Prirodnye Resursy [Georgephy and Natural Resources] 3: 60-66. DOI: 10.21782/ GIPR0206-1619-2019-3(60-66) (in Russian) 